\title{
Effect of dietary phospholipid levels on performance, enzyme activities and fatty acid composition of pikeperch (Sander lucioperca) larvae
}

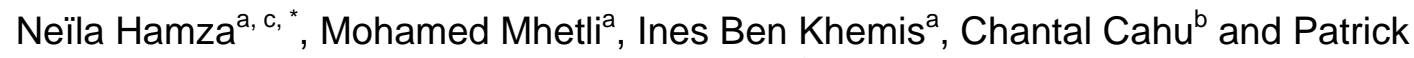 \\ Kestemont $^{\mathrm{C}}$
}

\author{
a Institut National des Sciences et Technologies de la Mer, 28, Rue 2 Mars 1934, 2025 Salammbo Tunisia \\ ${ }^{\mathrm{b}}$ Ifremer, UMR 1067, B.P.70 29280 Plouzane, France \\ c University of Namur (FUNDP), Unit of Research in Organismal Biology (URBO), Rue de Bruxelles, 61, B-5000 \\ Namur, Belgium
}

*: Corresponding author : Hamza N., email address : neilatun@yahoo.fr

\begin{abstract}
:
This study was carried out to evaluate the effects of dietary phospholipid on the development and rearing performance of pikeperch (Sander lucioperca) larvae. From day 10 post-hatching, fish larvae were weaned onto three isoproteic and isolipidic formulated diets with different phospholipid $(\mathrm{PL})$ levels: 1.4 (PL1), 4.7 (PL5) and 9.5\% (PL9) of dry matter, as soybean lecithin. Neutral lipid (NL) with inversed gradient was incorporated in diets. Survival, growth and deformities were monitored until day 34 post-hatching, as well as intestinal enzyme activities, leucine alanine peptidase (leu-ala), aminopeptidase $N(A N)$ and alkaline phosphatase (AP), which were used as indicators of digestive tract maturation. This study showed that PL supplementation significantly improved growth but not survival. The increase in dietary PL from 1.4 to $9.5 \%$ led to a $50 \%$ increase in larval final weight suggesting that high PL levels are needed during larval stages of pikeperch. The incidence of deformities was not affected by dietary phospholipid level. The specific activity of brush border membrane enzymes (AN and AP) increased with dietary phospholipid levels, indicating an earlier or more efficient maturation of digestive structures. A gut maturation index based on the ratio of segmental activity of the brush border membrane enzyme AP related to segmental activity of a cytosolic enzyme, leu-ala, was significantly higher in PL5 and PL9 groups compared to PL1 group indicating that $1 \%$ phospholipid incorporation in diet was not sufficient to induce good enterocyte maturation. Diet fatty acid composition was affected by phospholipid incorporation, dietary $n-3$ HUFA concentration decreasing with the incorporation of PL. Fatty acid composition in larvae reflected that of corresponding diet. The best results in growth and development obtained in the PL9 group seemed related to the PL entity, independently of its fatty acid composition. The results of this study indicate that pikeperch larvae have a relatively high PL requirement (at least $9.5 \%$ of the diet, dry weight).
\end{abstract}

Keywords: Digestive enzymes; Fatty acid; Larval development; Phospholipids; Pikeperch 


\section{Introduction}

Pikeperch (Sander lucioperca) is a valuable species for aquaculture due to its rapid growth, flesh quality and high commercial value. In Europe, production of pikeperch fingerlings depends mainly on extensive and semi-intensive pond culture (Hilge and Steffens, 1996; Zakes, 1997). In spite of the small size and fragility of percid larvae which have limited the development of percid culture (Kestemont and Mélard, 2000), a growing interest in the development of pikeperch intensive rearing has developed in several countries (Klein Breteler, 1989; Ruuhijärvi et al., 1991; Zakes, 1999; Molnar et al., 2004; Ostaszewska et al., 2005; Hamza et al., 2007; Kestemont et al., 2007).

The initial studies on early weaning of pikeperch larvae reported poor results in terms of survival and growth (Ruuhijärvi et al., 1991; Schlumberger and Proteau, 1991; Proteau et al., 1993; Mani-Ponset et al., 1994). More recent studies using commercial diets have indicated significant improvements in survival and growth with appropriate larval diets and/or optimal weaning timing (Ostaszewska et al., 2005; Kestemont et al., 2007). The initial studies on the digestive ontogeny and lipid metabolism were essentially based on histological and cytochemical studies (Mani-Ponset et al., 1994; Diaz et al., 1997). A recent investigation using an enzymatic approach indicated that the digestive capacities of pikeperch larvae was affected by diet (live prey or compound diet) and weaning time (Hamza et al., 2007).

Until now, there is no feed specifically formulated for percid fishes (Kestemont and Mélard, 2000). Hilge and Steffens (1996) considered that the lack of an adequate formulated diet considerably limited further development of pikeperch fry intensive culture. Data concerning the nutritional requirements of percid fishes are scarce (Brown et al., 1996; Fiogbé et al., 1996; Kestemont et al., 1996; 2001) and, concerning pikeperch, are limited to the juvenile stage (Nyina-wamwiza et al., 2005; Schulz et al., 2005; 2006; Molnar et al., 2006). Knowledge of nutritional requirements and enzymatic capacities during the early life stages is thus needed.

It is well known that lipids constitute a major energy source for fish (Bell and Tocher, 1989) and play a critical role in larval development (Rainuzzo et al., 1997; Sargent et al., 1999). Also phospholipids (PL) have been demonstrated to significantly affect survival, growth, deformities and/or resistance to stress in several fish and crustacea (Kanazawa, 1985; Kanazawa et al., 1985; Geurden et al., 1995; 1998; Koven et al., 1998; Cahu et al., 2003; Gisbert et al., 2005). They play a major role in maintaining the structure and function of cellular membranes (Kanazawa, 1985; Tocher, 2003). They have been reported to act as emulsifiers in the gut (Koven et al., 1993) and to improve intestinal absorption of long chain fatty acids (Fontagné et al., 2000). Moreover, they stimulate lipoprotein synthesis in intestinal enterocytes (Fontagné et al., 1998; Geurden et al., 1998) and play an important role in the transport of dietary lipids (Kanazawa, 1991; Teshima et al., 1986). Few studies have demonstrated their effect on the maturation of digestive structures of fish larvae (Cahu et al., 2003; Gisbert et al., 2005; Morais et al., 2007).

Fatty acids are known to play a crucial role in membrane structure (Tocher, 2003). The n-3 (18:3; 20:5 and 22:6) and n-6 (18:2 and 20:4) fatty acids are essential for normal growth and survival of fish, which do not possess the capacity to synthesize them. Freshwater fish species have bioconversion capacity, allowing them to transform precursors (in particular 18:3n-3 and 18:2n-6) into highly unsaturated fatty acids (HUFA), as has been demonstrated in rainbow trout and Japanese eel by Kanazawa et al. (1979) and more recently for pike by Buzzi et al. (1997).

Considering the importance of PL for fish species, particularly during early life stages, when larvae are unable to synthesize them efficiently (Geurden et al., 1995; Coutteau et al., 1997; Fontagné et al., 1998), this study was carried out to evaluate the effects of dietary PL on survival, growth, deformities, digestive enzyme activities and fatty acid composition of pikeperch larvae.

\section{Materials and methods}

\subsection{Facilities and fish}

Pikeperch (Sander lucioperca) larvae were obtained from a private hatchery (Viskweekcentrum Valkenswaard, The Netherlands) and transferred to INSTM (Institut National des Sciences et Technologies de la Mer, Tunisia) on day 2 post hatching (ph). Upon arrival, the larvae were acclimated in two 500 I tanks $\left(20-22^{\circ} \mathrm{C}\right)$ supplied with U.V.-sterilized recycled fresh water. From mouth opening, on day 4 ph, they were fed ad libitum each hour from 0080 to $2000 \mathrm{~h}$, on newly hatched small size 
Artemia nauplii (AF, INVE Belgium). On day $10 \mathrm{ph}$, the larvae were transferred to the experimental unit in a recirculating system containing 12 cylindroconical tanks of 60 I each. Four tanks were randomly assigned to each experimental group. Initial stocking density was 20 larvae $\mathrm{I}^{-1}$. Temperature and dissolved $\mathrm{O}_{2}$, controlled daily, were maintained at $21-23^{\circ} \mathrm{C}$ and above $6 \mathrm{mg} \mathrm{l}^{-1}$, respectively, with a water exchange of up to $100 \% \mathrm{~h}^{-1}$ (flow rate: $1 \mathrm{I} \mathrm{min}^{-1}$ ). Nitrites and ammonia were determined twice a week and maintained at levels lower than 0.1 and $1 \mathrm{mg} \mathrm{l}^{-1}$, respectively. The larvae were kept under low light intensity (30 lux maximum) except during cleaning and feeding. Tanks were cleaned by siphoning twice a day to remove the faeces and dead larvae.

\subsection{Experimental diets}

From day 10 to day $34 \mathrm{ph}$, larvae were fed one of three isoproteic and isolipidic microdiets (Table 1 ) formulated according to the patent W00064273 (registered in World Intellectual Property Organization, November 2000) and containing modified levels of soybean lecithin (Etablissement Louis François) and cod liver oil to obtain three PL levels: 1.5 (PL1), 4.7 (PL5), and 9.5\% (PL9). Microdiets were processed as follows: dietary ingredients were mechanically mixed with water, pelleted and dried at $50^{\circ} \mathrm{C}$ for $20 \mathrm{~min}$. The pellets were sieved to obtain two sizes of particles: 200 $400 \mu \mathrm{m}$ used during the first week, then $400-700 \mu \mathrm{m}$ until the end of the experiment. Feed was distributed manually every $30 \mathrm{~min}$ from 0080 to $2000 \mathrm{~h}$.

The feeding levels were fixed at 25, 20, 15 and $10 \%$ of larval wet weight during the first, second, third and fourth week, respectively, corresponding to $1-5 \mathrm{~g} \operatorname{tank}^{-1} \mathrm{day}^{-1}$. A period of co-feeding (day 10-15) was applied to wean the larvae to the dry diet. During co-feeding, at least four meals were given prior any distribution of newly hatched Artemia nauplii (EG, INVE Belgium).

Table 1. Composition of the three experimental diets containing different levels of phospholipid (PL).

\begin{tabular}{|c|c|c|c|}
\hline Diet Ingredients ${ }^{\mathrm{a}}(\%)$ & PL1 & PL5 & PL9 \\
\hline Fish meal & 60 & 60 & 60 \\
\hline Hydrolyzed fish meal CPSP G & 14 & 14 & 14 \\
\hline Cod liver oil & 13 & 7 & 0 \\
\hline Soybean lecithin ${ }^{b}$ & 0 & 6 & 13 \\
\hline Vitamin mixture $^{c}$ & 8 & 8 & 8 \\
\hline Mineral mixture ${ }^{d}$ & 4 & 4 & 4 \\
\hline Betaine & 1 & 1 & 1 \\
\hline \multicolumn{4}{|l|}{ Lipid composition(\% DM) } \\
\hline Neutral lipids & 20.6 & 14.2 & 8.5 \\
\hline Phospholipids & 1.4 & 4.7 & 9.5 \\
\hline \multicolumn{4}{|l|}{ Proximal composition (\% DM) } \\
\hline Crude protein & 58 & 58 & 58 \\
\hline Crude lipids & 22 & 20 & 20 \\
\hline Ash & 12.0 & 12.5 & 13.2 \\
\hline$\%$ dry matter & 96.2 & 95.3 & 90.5 \\
\hline Protein energy+lipid energy $\left(\mathrm{kJ} \mathrm{kg}^{-1}\right)^{\mathrm{e}}$ & 18.0 & 17.2 & 17.2 \\
\hline
\end{tabular}

a Dietary ingredients were commercially obtained. Fish meal, hydrolyzed fish meal (CPSP G, Concentré de Protéines Solubles de Poissons) and cod liver oil from La Lorientaise (Lorient, France). The soy lecithin was from Ets Louis François (St Maur des Fossés, France).

${ }^{b}$ Soybean lecithin, contains: phospholipids $620 \mathrm{~g} \mathrm{~kg}-1$ including $260 \mathrm{~g}$ phosphatidylcholine, $200 \mathrm{~g}$ phosphatidylethanolamine and $140 \mathrm{~g}$ phosphatidylinositol

${ }^{c}$ Per $\mathrm{kg}$ of vitamin mix: choline chloride : $200 \mathrm{~g}$, retinyl acétate $0.34 \mathrm{~g}$, all-rac- $\alpha$-tocopherol $10 \mathrm{~g}$, cholecalciferol $0.5 \mathrm{~g}$, niacin $1 \mathrm{~g}$, D-calcium pantothenate $2 \mathrm{~g}$, thiamin $100 \mathrm{mg}$, riboflavine $400 \mathrm{mg}$, pyridoxin $0.3 \mathrm{~g}$, ascorbic acid $20 \mathrm{~g}$, folic acid $0.1 \mathrm{~g}$, cyanocobalamin $1 \mathrm{~g}$, biotine $1 \mathrm{~g}$, menadione $1 \mathrm{~g}$, meso-inositol $30 \mathrm{~g}$. 
${ }^{d}$ Per kg of mineral mix: $\mathrm{KCl} 90 \mathrm{~g}, \mathrm{KL}_{4} \mathrm{O} 40 \mathrm{mg}, \mathrm{CaHPO}_{4} 2 \mathrm{H} 2 \mathrm{O} 500 \mathrm{~g}, \mathrm{NaCl} 40 \mathrm{~g}$, $\mathrm{CuSO}_{4} \cdot 5 \mathrm{H} 2 \mathrm{O} 3 \mathrm{~g}$, $\mathrm{ZnSO}_{4} \cdot 7 \mathrm{H} 2 \mathrm{O} 4 \mathrm{~g}, \mathrm{CoSO}_{4} \cdot 7 \mathrm{H} 2 \mathrm{O} 20 \mathrm{mg}, \mathrm{FeSO}_{4} \cdot 7 \mathrm{H} 2 \mathrm{O} 20 \mathrm{~g}, \mathrm{MnSO}_{4} \cdot \mathrm{H} 2 \mathrm{O} 3 \mathrm{~g}, \mathrm{CaCO}_{3} 215 \mathrm{~g}, \mathrm{MgSO}_{4} \cdot 7 \mathrm{H} 2 \mathrm{O}$ $124 \mathrm{~g}, \mathrm{NaF} 1 \mathrm{~g}$.

${ }^{\mathrm{e}}$ Calculated as : lipid $\times 37.7 \mathrm{~J} \mathrm{~kg}^{-1}$; protein $\times 16.7 \mathrm{~J} \mathrm{~kg}^{-1}$

\subsection{Sampling procedures}

Growth was monitored by sampling 30 larvae per tank on days 4 and 10 ph, and 10 larvae per tank on days $16,22,28$ and $34 \mathrm{ph}$. The larvae were weighed collectively from day 0 to day 22 , and individually on days 28 and 34 . At the end of the experiment the weighed larvae were also examined to determine the rate of malformations (lordosis, scoliosis, jaw injury).

The number of sampled larvae was taken into account for survival calculation.

Growth, survival and deformity parameters were calculated as follows:

Instantaneous specific growth rate $\left(\mathrm{SGR}, \%\right.$ day $\left.^{-1}\right)=100(\mathrm{LnWf}-\mathrm{LnWi}) \Delta \mathrm{T}^{-1}$

Survival $(\mathrm{S}, \%)=100 \mathrm{Nf} /(\mathrm{Ni}-\mathrm{Ns})$

Deformities $(\mathrm{D}, \%)=100 \mathrm{Nd} / \mathrm{Ns}$

where $\mathrm{Wf}, \mathrm{Wi}=$ final and initial weight of larvae (mg), T= time (days); $\mathrm{Nf}, \mathrm{Ni}=$ final and initial number of larvae; Nd: Number of larvae presenting deformity and Ns: Number of sampled larvae.

To estimate the number of larvae which ingested the feed, in the first two days of co-feeding, 10 larvae per tank were collected in a glass becher to observe the presence (or not) of the dry diet in digestive tract.

To determine the pattern of enzyme activity, about 240 larvae were collected on day 10 and then 70 , 30,20 , and 20 larvae per tank on days 16, 22, 28 and 34, respectively. On day 34,20 larvae per tank were collected for analysis of total lipids, lipid class and fatty acids. Samples were taken before feed distribution and immediately stored at $-80^{\circ} \mathrm{C}$ until analysis.

\subsection{Enzyme assays}

The heads and tails of ten day old larvae were removed to isolate the digestive segment. Older larvae were dissected as described by Cahu and Zambonino (1994), on a glass maintained on ice $\left(0^{\circ} \mathrm{C}\right)$ under a binocular, to separate their intestinal segments. Pooled samples from each tank were homogenized in 10 volumes (v/w) of ice-cold distilled water. Leucine alanine peptidase (leu-ala), an enzyme of the cytosol, was assayed according to Nicholson and Kim (1975) using leucine-alanine (Sigma-Aldrich, St Louis, MO, USA) as substrate. Alkaline phosphatase (AP) and aminopeptidase N (AN), two enzymes of brush border membrane, were assayed according to Bessey et al. (1946) and Maroux et al. (1973) using p-nitrophenyl phosphate (Sigma-Aldrich) and L-leucine p-nitroanilide (Sigma-Aldrich) as substrates, respectively.

Enzyme activities are expressed as specific activities $\left(U \mathrm{mg}\right.$ protein $\left.{ }^{-1}\right)$ or as segmental activities (U per dissected intestinal segment). Protein was determined using the Bradford (1976) procedure.

\subsection{Lipid and fatty acid analysis}

Samples of 34 day old larvae were homogenized by ultraturax T10 (IKA). The lipid content in diets and larvae was analyzed after extraction with chloroform/methanol $(2: 1 \mathrm{v} / \mathrm{v})$ according to the method of Folch et al. (1957). Whole body crude lipids were subsequently separated into polar and non polar fractions using Sep-Pak Silica cartridges (Waters, Milford, MA, USA). Chloroform and methanol were used as the mobile phases for neutral lipids (NL) and phospholipids, respectively (Juaneda and Rocquelin, 1985). The fatty acid methyl esters were prepared by transesterification with borontrifluoride in methanol as described by Metcalfe et al. (1966) and then separated by gas chromatography using an Agilent Technologies chromatograph 6890N (Agilent Technologies, Palo Alto, CA, USA) equipped with a flame ionization detector (FID), a splitless injector and a polar INNOWAX 30M silica capillary column $(0.25 \mathrm{~mm}$ i.d. and $0.25 \mu \mathrm{m}$ film thickness). The temperature of the injector and detector were $220^{\circ}$ and $275^{\circ} \mathrm{C}$ respectively. Helium was used as a carrier gas at a flow rate of $1.5 \mathrm{ml} \mathrm{min}^{-1}$.

The fatty acid composition of the three diets PL1, PL5 and PL9 is detailed in Table 2. 


\subsection{Statistical analyses}

Results are given as mean values and standard deviations. Survival, malformations and fatty acid percentages were arcsin transformed. AP segmental activity was log10 transformed and AP/leu-ala (segmental activities) ratios were $\arcsin \left(x^{1 / 2}\right)$ transformed $(Z a r, 1999)$. Data were compared by a oneway ANOVA followed by a LSD test when significant differences were found at $P<0.05$. Specific enzyme activities were log10 transformed and compared by a two-way ANOVA followed by the Tukey HSD test when significant differences were found at $P<0.05$. The two analyzed factors were age and phospholipid level. The homogeneity of variances was first checked using the Levene's test.

Table 2. Fatty acid composition (\% of total fatty acids) of the phospholipid (PL) and neutral lipid (NL) fractions of the experimental diets PL1, PL5 and PL9.

\begin{tabular}{|c|c|c|c|c|c|c|}
\hline \multirow[b]{2}{*}{ Fatty acid } & \multicolumn{2}{|c|}{ PL1 } & \multicolumn{2}{|c|}{ PL5 } & \multicolumn{2}{|c|}{ PL9 } \\
\hline & $\mathrm{NL}$ & $\mathrm{PL}$ & $\mathrm{NL}$ & $\mathrm{PL}$ & NL & $\mathrm{PL}$ \\
\hline $14: 0$ & 5.5 & 2.1 & 5.4 & 0.6 & 4.3 & 0.3 \\
\hline $16: 0$ & 15.0 & 21.4 & 14.9 & 20.6 & 15.4 & 20.7 \\
\hline $18: 0$ & 2.8 & 4.3 & 2.6 & 3.7 & 2.6 & 3.7 \\
\hline$\Sigma$ Sat & 23.3 & 27.8 & 22.9 & 24.9 & 22.3 & 24.7 \\
\hline $16: 1 n-7$ & 6.7 & 2.8 & 6.8 & 0.8 & 6.1 & 0.4 \\
\hline $18: 1 n-7$ & 3.5 & 3.8 & 3.6 & 1.9 & 4.0 & 1.7 \\
\hline $20: 1 n-7$ & 0.4 & 0.3 & 0.4 & 0.1 & 0.4 & 0.0 \\
\hline $18: 1 n-9$ & 14,6 & 13,8 & 14,7 & 11,3 & 15,3 & 10,9 \\
\hline $20: 1 n-9$ & 7.6 & 2.9 & 7.6 & 0.8 & 8.7 & 0.4 \\
\hline 22:1n-11 & 7.8 & 1.3 & 7.7 & 0.4 & 9.1 & 0.2 \\
\hline$\Sigma$ Monounsat & 40.6 & 24.9 & 40.8 & 15.3 & 43.6 & 13.6 \\
\hline $18: 2 n-6$ & 2.4 & 1.6 & 2.5 & 44.0 & 3.5 & 50.1 \\
\hline $20: 2 n-6$ & 0,3 & 0,2 & 0,3 & 0,1 & 0,3 & 0,1 \\
\hline $20: 4 n-6$ & 0.6 & 1.7 & 0.6 & 0.4 & 0.6 & 0.2 \\
\hline$\Sigma \mathrm{n}-6$ & 3.3 & 3.5 & 3.4 & 44.5 & 4.4 & 50.4 \\
\hline $18: 3 n-3$ & 1.0 & 0.5 & 1.1 & 4.0 & 1.1 & 4.5 \\
\hline $18: 4 n-3$ & 2.5 & 0.8 & 2.7 & 0.2 & 2.5 & 0.1 \\
\hline $20: 4 n-3$ & 1.1 & 0.6 & 1.1 & 0.2 & 0.7 & 0.1 \\
\hline $20: 5 n-3$ & 10.6 & 12.2 & 10.9 & 3.1 & 9.7 & 1.7 \\
\hline $22: 5 n-3$ & 2.0 & 1.4 & 1.7 & 0.3 & 0.9 & 0.2 \\
\hline $22: 6 n-3$ & 11.0 & 24.8 & 11.0 & 6.3 & 10.0 & 3.5 \\
\hline$\sum n-3$ & 28.2 & 40.3 & 28.5 & 14.1 & 24.9 & 10.1 \\
\hline n-3HUFA & 27.2 & 39.8 & 27.4 & 10.1 & 23.8 & 5.6 \\
\hline$n-3 / n-6$ & 8.55 & 11.51 & 8.38 & 0.32 & 5.66 & 0.20 \\
\hline $\begin{array}{l}\text { Polyunsat/Sat } \\
\text { EPA+DHA }\end{array}$ & 1.35 & 1.57 & 1.39 & 2.35 & 1.31 & 2.45 \\
\hline (\%diet dry weight) & 3.99 & 0.28 & 2.37 & 0.25 & 1.01 & 0.24 \\
\hline $\begin{array}{l}\text { Total EPA+DHA } \\
\text { (\%diet dry weight) }\end{array}$ & & & & & & \\
\hline
\end{tabular}

Sat : Saturated, Monounsat: monounsaturated, Polyunsat : Polyunsaturated 


\section{Results}

\subsection{Larval zootechnical performance}

The artificial diets were ingested by 80 to $100 \%$ of the larvae from the second day of co-feeding. The survival at the end of the experiment averaged $35 \%$ and no significant differences were observed among the experimental groups. The mortality reached a peak on day 12 independent of treatment. Between day 16 and 21, mortality remained relatively high (2 to $4 \%$ day $^{-1}$ ) and decreased from day 22 onwards.

From day 10 to day 34 larval weight increased 32-fold for the PL1 group to 48-fold for the PL9 group. A significant effect of dietary level of phospholipids on larval growth was detected from day 28 onwards, with PL9 larvae having significantly higher weights than PL1 larvae $(P<0.01)$. The PL5 group was not different either from the PL1 or PL9 groups. At the end of the experiment, the growth (final weight and SGR) of PL9 larvae was significantly higher $(P<0.01)$ than that of the two other groups, followed by the PL5 group, which grew significantly more $(P<0.01)$ than the PL1 group (Fig. 1 and Table 3).

The deformities observed were almost exclusively limited to lordosis (the number of larvae suffering from scoliosis or incomplete jaw development was considered negligible). Malformations varied between 7 and 12\% but no significant differences were found among treatments.

Fig. 1. Growth of pikeperch larvae fed different dietary phospholipid (PL) levels (PL1, PL5, PL9 = 1, 5

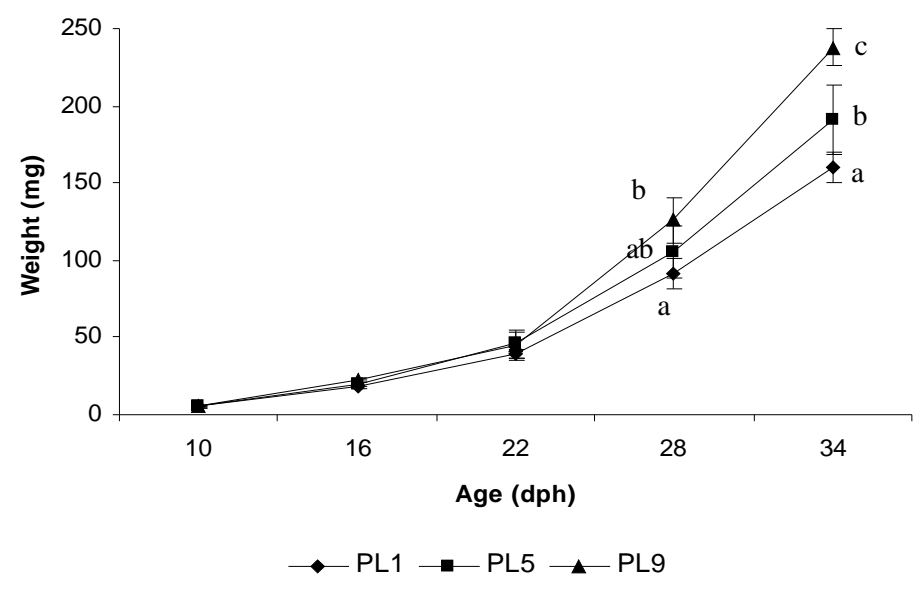

and $9 \%$ of phospholipids, respectively). Age is expressed in days post-hatching (dph).

Table 3. Survival, growth and percent deformities in the three experimental groups of pikeperch larvae fed different levels of dietary phospholipid, at the end of the experimental period.

\begin{tabular}{lccc}
\hline & PL1 & PL5 & PL9 \\
\hline Survival (\%) & $34 \pm 1.5 \mathrm{a}$ & $36.6 \pm 2.5 \mathrm{a}$ & $33 \pm 3.1 \mathrm{a}$ \\
SGR $\left(\%\right.$ day $^{-1}$ ) & $14.1 \pm 0.2 \mathrm{a}$ & $14.8 \pm 0.5 \mathrm{~b}$ & $15.8 \mathrm{c} \pm 0.2 \mathrm{c}$ \\
Total deformity (\%) & $12.5 \pm 12.5 \mathrm{a}$ & $12.5 \pm 15.0 \mathrm{a}$ & $7.5 \pm 9.6 \mathrm{a}$ \\
\hline
\end{tabular}

Means $\pm S D(n=4)$ Values with different letters in the same line are significantly different $(P<0.05)$

\subsection{Enzyme activities}

Leu-ala specific activity decreased significantly between days 16 and 22 and then, increased significantly in all groups. No differences were observed among groups during the feeding trial regardless of dietary treatment (Fig. 2A). AP specific activity significantly increased from day 10 to day 16 and then, significantly decreased until day 34. On days 22 and 28, the PL5 and PL9 diets induced significantly higher AP activity than the PL1 diet. No more differences were observed among 
treatments at the end of the experiment. (Fig 2B). AN specific activity significantly increased in all groups between days 10 and 16. It then significantly increased between day 16 and 22 exclusively for PL9 larvae and decreased for the PL1 group. On day 22, AN activity was at a significantly higher level in the PL9 group than in PL5 and PL1 groups. No more differences were noticed among the different larval groups from day 28 until the end of the experiment (Fig 2C).

AP segmental activity ( $\mathrm{mU}$ fish ${ }^{-1}$ ) was significantly affected by age and treatment $(P=0.02)$. It was significantly higher in the PL5 and PL9 groups than in PL1 larvae on day 22 (Table 4). On days 28 and 34, AP segmental activity was significantly higher in PL9 larvae than in the two other groups.

The ratio of segmental activity of the brush border membrane enzyme AP related to the segmental activity of a cytosolic enzyme, leu-ala, was significantly higher in the PL5 and PL9 groups compared to the PL1 group on day 28 (Table 4).

A

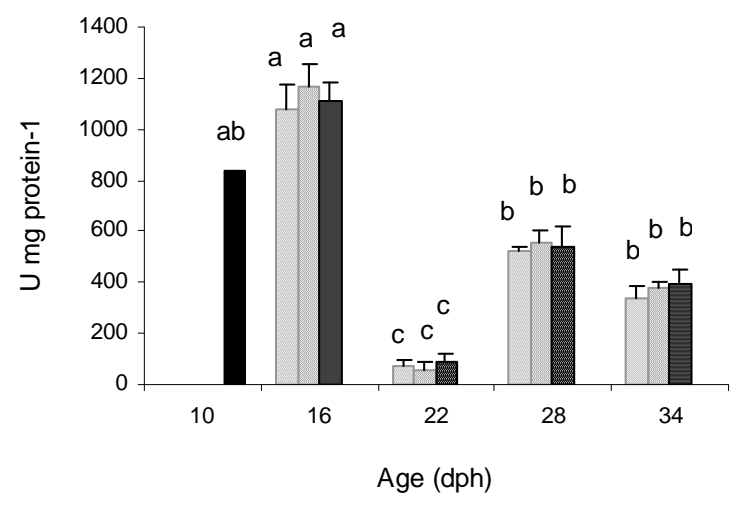

A

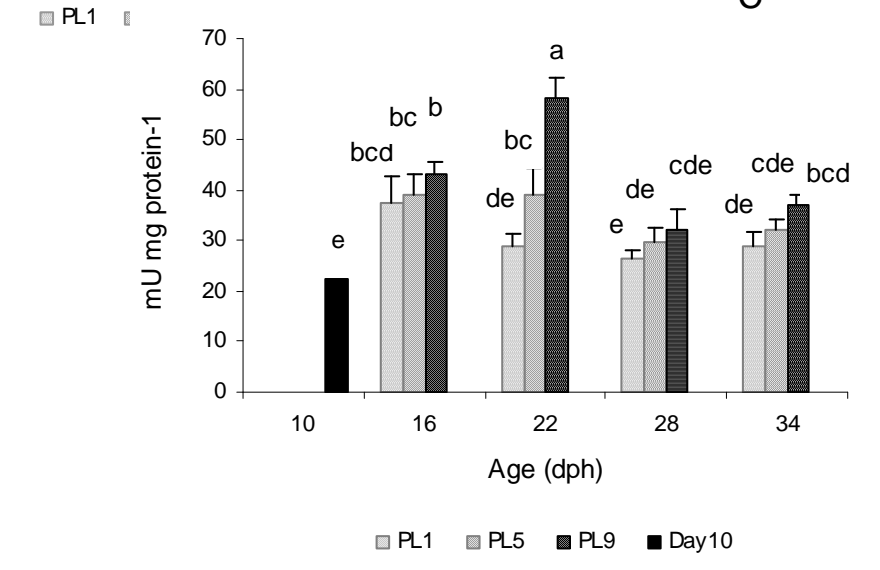

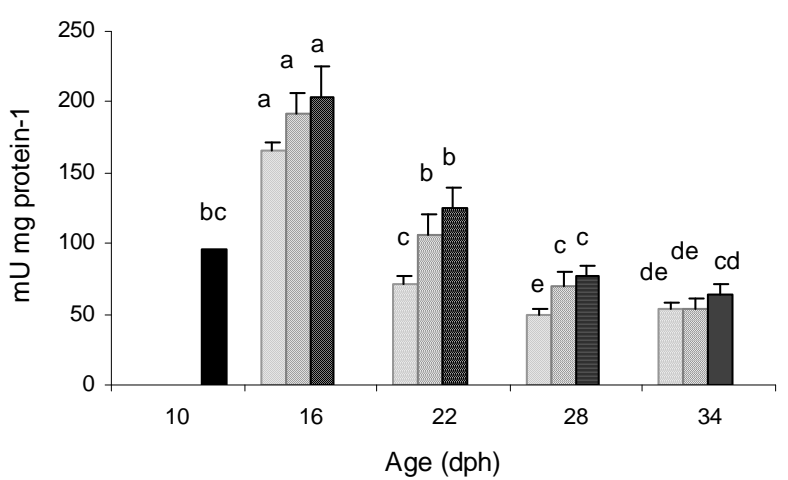

$\square$ PL5 뭉 PL9 Day10

Fig. 2. Specific activity of (A) leucine alanine peptidase, (B) alkaline phosphatase and (C) aminopeptidase $\mathrm{N}$ during larval development of pikeperch fed with different dietary phospholipid levels (PL1, PL5, PL9 $=1,5$ and 9\% of phospholipids, respectively). Data are means \pm SD $(n=4)$. Age is expressed in days post-hatching (dph). Bars with different superscript letters are significantly different ( $P<0.05$; two way ANOVA followed by Tukey HSD).

Table 4. AP segmental activity on days 22,28 and 34 and AP/leu-ala ratio (day 28) in pikeperch larvae fed different dietary phospholipid levels (PL1, PL5, PL9 $=1,5$ and $9 \%$ of phospholipids, respectively). Age is expressed in days post-hatching.

\begin{tabular}{lccc}
\hline & PL1 & PL5 & PL9 \\
\hline AP segmental activity & & & \\
Day 22 & $52.1 \pm 1.0 \mathrm{a}$ & $92.0 \pm 17.0 \mathrm{~b}$ & $87.4 \pm 17.0 \mathrm{~b}$ \\
Day 28 & $88.4 \pm 21.4 \mathrm{a}$ & $134.8 \pm 21.0 \mathrm{~b}$ & $189.7 \pm 34.7 \mathrm{c}$ \\
Day 34 & $189.5 \pm 8.5 \mathrm{a}$ & $222.4 \pm 15.9 \mathrm{~b}$ & $287.2 \pm 33.1 \mathrm{c}$ \\
\hline AP/Leu-ala $\left(10 \mathrm{exp}^{-3}\right)$ & $0.09 \pm 0.01 \mathrm{a}$ & $0.12 \pm 0.01 \mathrm{~b}$ & $0.14 \pm 0.02 \mathrm{~b}$ \\
\hline
\end{tabular}

Means $\pm S D(n=4)$ Values with different letters in the same line are significantly different $(P<0.05)$ 


\subsection{Fatty acid composition}

The main differences in fatty acid composition of the diets were noticeable in the PL fraction and concerned essentially n- 6 and n-3 fatty acid series. The n- 6 fatty acids varied from $3 \%$ (PL1) to $50 \%$ (PL9) and this change was mainly related to the increase of the 18:2n-6. All the n-3 fatty acids decreased except the 18:3n-3 which increased (from 0.5\% in PL1 to 4.5\% in PL9 diet) (Table 2).

The fatty acid composition of the larvae (Table 5) was globally influenced by the fatty acid composition of the corresponding diet in its NL and PL fractions. The PL (from soybean lecithin) supplementation resulted in a decrease of monounsaturated fatty acids and n-3 polyunsaturated fatty acids (PUFA) (except 18:3n-3), and in an increase of $n-6$ fatty acids (18:2n-6) in larval fatty acid composition. The main $n-6$ and $n-3$ polyunsaturated fatty acids, 20:4n-6 (ARA; arachidonic acid), 20:5n-3 (EPA; eicosapentaenoic acid), 22:5n-3 (DPA; docosapentaenoic acid) and 22:6n-3 (DHA; docosahexaenoic acid) presented a higher concentration in the PL fraction than in the NL fraction. The percentage of 18:2n- 6 was two fold higher in the NL than in the PL fraction.

Table 5. Fatty acid composition (\% of total fatty acids) in the phospholipid (PL) and neutral lipid (NL) fractions of pikeperch larvae (day 34) fed different dietary phospholipid levels (PL1, PL5, PL9 = 1, 5 | and $9 \%$ of phospholipid respectively

\begin{tabular}{|c|c|c|c|c|c|c|}
\hline \multirow[b]{2}{*}{ Fatty acid } & \multicolumn{3}{|c|}{ NL } & \multicolumn{3}{|c|}{ PL } \\
\hline & PL1 & PL5 & PL9 & PL1 & PL5 & PL9 \\
\hline $14: 0$ & $15.02 \pm 0.17 a$ & $12.23 \pm 0.54 b$ & $7.80 \pm 0.20 c$ & $4.78 \pm 0.35 a$ & $3.82 \pm 0.19 b$ & $2.54 \pm 0.51 \mathrm{c}$ \\
\hline 16:0 & $20.26 a \pm 0.91 a$ & $22.18 \pm 0.62 b$ & $25.46 \pm 0.86 c$ & $36.34 \pm 1.52 \mathrm{a}$ & $39.75 \pm 0.49 b$ & $38.88 \pm 1.05 b$ \\
\hline 18:0 & $0.55 \pm 0.05 a$ & $0.39 \pm 0.04 b$ & $0.17 \pm 0.01 \mathrm{c}$ & $0.42 \pm 0.15 a$ & $0.67 \pm 0.55 a$ & $0.32 \pm 0.13 a$ \\
\hline$\Sigma$ Sat. & $35.83 \pm 0.97 a$ & $34.80 \pm 0.58 a$ & $33.43 \pm 0.90 b$ & $41.54 \pm 1.88 \mathrm{a}$ & $44.24 \pm 0.46 a$ & $41.74 \pm 0.85 a$ \\
\hline $16: 1 n-7$ & $14.80 \pm 0.40 a$ & $11.90 \pm 0.37 b$ & $8.59 \pm 0.12 c$ & $3.64 \pm 2.03 a$ & $3.84 \pm 0.14 b$ & $1.80 \pm 0.41 \mathrm{c}$ \\
\hline $18: 1 n-7$ & $2.43 \pm 0.28 a$ & $2.00 \pm 0.16 a$ & $1.92 \pm 0.37 a$ & $2.08 \pm 0.15 a$ & $1.98 \pm 0.10 a b$ & $1.76 \pm 0.11 b$ \\
\hline $18: 1 n-9$ & $15.25 \pm 0.59 a$ & $14.30 \pm 0.14 b$ & $13.72 \pm 0.21 \mathrm{~b}$ & $11.21 \pm 0.31 \mathrm{a}$ & $10.95 \pm 0.38 a$ & $10.14 \pm 0.01 b$ \\
\hline$\sum_{\Sigma}^{20: 1 n-9}$ & $2.97 \pm 0.14 a$ & $2.67 \pm 0.10 \mathrm{~b}$ & $2.40 \pm 0.12 \mathrm{c}$ & $1.59 \pm 0.10 \mathrm{a}$ & $1.37 \pm 0.08 b$ & $1.24 \pm 0.03 b$ \\
\hline Monounsat. & $32.48 \pm 1.16 a$ & $28.19 \pm 0.39 b$ & $24.22 \pm 0.24 \mathrm{c}$ & $18.52 \pm 1.72 \mathrm{a}$ & $18.14 \pm 0.61 b$ & $15.28 \pm 1.01 \mathrm{c}$ \\
\hline $18: 2 n-6$ & $2.72 \pm 0.09 a$ & $11.41 \pm 0.11 b$ & $22.45 \pm 0.71 \mathrm{c}$ & $1.03 \pm 0.12 a$ & $5.12 \pm 0.04 b$ & $11.48 \pm 0.62 \mathrm{c}$ \\
\hline $20: 4 n-6$ & $0.42 \pm 0.03 a$ & $0.30 \pm 0.03 b$ & $0.20 \pm 0.03 c$ & $1.33 \pm 0.04 a$ & $1.20 \pm 0.03 b$ & $0.92 \pm 0.05 c$ \\
\hline$\Sigma \mathrm{n}-6$ & $3.14 \pm 0.11 \mathrm{a}$ & $11.70 \pm 0.12 b$ & $22.64 \pm 0.71 \mathrm{c}$ & $2.36 \pm 0.13 a$ & $6.32 \pm 0.07 b$ & $12.41 \pm 0.61 \mathrm{c}$ \\
\hline $18: 3 n-3$ & $0.84 \pm 0.03 a$ & $1.30 \pm 0.04 b$ & $1.89 \pm 0.03 \mathrm{c}$ & $0.23 \pm 0.02 a$ & $0.35 \pm 0.00 \mathrm{~b}$ & $0.59 \pm 0.05 c$ \\
\hline $18: 4 n-3$ & $1.83 \pm 0.09 a$ & $1.43 \pm 0.09 \mathrm{~b}$ & $1.03 \pm 0.05 c$ & $0.29 \pm 0.02 a$ & $0.25 \pm 0.01 \mathrm{ab}$ & $0.22 \pm 0.04 b$ \\
\hline $20: 4 n-3$ & $0.51 \pm 0.02 \mathrm{a}$ & $0.35 \pm 0.01 \mathrm{~b}$ & $0.18 \pm 0.01 \mathrm{c}$ & $0.26 \pm 0.02 a$ & $0.21 \pm 0.01 b$ & $0.16 \pm 0.00 c$ \\
\hline $20: 5 n-3$ & $4.96 \pm 0.09 a$ & $3.23 \pm 0.07 b$ & $1.85 \pm 0.11 \mathrm{c}$ & $5.69 \pm 0.16 a$ & $5.62 \pm 0.14 a$ & $4.94 \pm 0.19 b$ \\
\hline $22: 5 n-3$ & $0.96 \pm 0.05 a$ & $0.63 \pm 0.04 b$ & $0.34 \pm 0.03 c$ & $0.94 \pm 0.05 a$ & $0.79 \pm 0.02 b$ & $0.65 \pm 0.04 c$ \\
\hline $22: 6 n-3$ & $4.70 \pm 0.17 a$ & $3.22 \pm 0.23 b$ & $2.31 \pm 0.23 c$ & $13.14 \pm 0.45 a$ & $11.41 \pm 0.12 b$ & $10.01 \pm 0.89 c$ \\
\hline$\Sigma \mathrm{n}-3$ & $13.80 \pm 0.39 a$ & $10.16 \pm 0.26 b$ & $7.61 \pm 0.29 c$ & $20.56 \pm 0.63 a$ & $18.64 \pm 0.13 b$ & $16.53 \pm 0.80 \mathrm{c}$ \\
\hline$\Sigma$ HUFA & $11.13 \pm 0.29 a$ & $7.42 \pm 0.22 b$ & $4.68 \pm 0.34 c$ & $20.04 \pm 0.65 a$ & $18.03 \pm 0.13 b$ & $15.72 \pm 0.88 c$ \\
\hline$n-3 / n-6$ & $4.40 \pm 0.26 a$ & $0.87 \pm 0.03 b$ & $0.34 \pm 0.02 c$ & $8.74 \pm 0.75 a$ & $2.95 \pm 0.05 b$ & $1.34 \pm 0.11 \mathrm{c}$ \\
\hline Polyunsat/sat & $0.47 \pm 0.01 \mathrm{a}$ & $0.62 \pm 0.01 \mathrm{~b}$ & $0.90 \pm 0.04 c$ & $0.55 \pm 0.03 a$ & $0.56 \pm 0.01 \mathrm{a}$ & $0.69 \pm 0.02 b$ \\
\hline
\end{tabular}


Sat : Saturated, Monounsat: monounsaturated, Polyunsat : Polyunsaturated

Means $\pm S D(n=4)$. Values with different superscript letters in the same line per fraction are significantly different $(P<0.05)$ HUFA Highly Unsaturated Fatty Acids;

DHA : Docosahexaenoic acid (22:6n-3); EPA : Eicosapentaenoic acid (C20:5n-3)

\section{Discussion}

During the experiment, pikeperch larvae ingested readily the microparticulate diets as early as the 11th day (second day of co-feeding).

The survival of larvae fed the different compound diets varied between 33 and $36 \%$ and was not significantly affected by the dietary PL level. According to our morphometric observations, the peak of mortality observed on day 12 occurred concurrently with the depletion of exogenous nutritional reserves (yolk sac and oil globule). In a previous study, histological observations (Hamza et al., 2007) showed a resorption of reserves around day 9 p.h.. Between days 16 and 21, the relatively high mortality probably concerned the larvae that did not ingest enough feed and reached the point of no return, while in the last two weeks of the experiment the mortality was essentially due to cannibalism. In the same way, Szkudlarek et al. (2007) reported three phases of mortality in pikeperch larval rearing which were related to the beginning of the exogenous feeding (days 4-6), swimbladder inflation (days 8-14) and cannibalism (days 22-34). This last period coincides with an important cannibalism in our study.

The final mean weight of larvae ranged between 160 and $240 \mathrm{mg}$ and was significantly influenced by dietary PL level $(P=0.0002)$. The increase in dietary PL level from 1.5 to $9.5 \%$ (dry diet weight) led to a $50 \%$ increase in larval final weight suggesting that high PL levels are needed during larval stages of pikeperch. A similar conclusion was reached by Zambonino and Cahu (1999) for European sea bass.

The positive effect of PL on fish growth especially at the larval stage has been shown for freshwater species like common carp (Geurden et al., 1995; Fontagné et al., 2000) and marine species like European sea bass (Cahu et al., 2003; Gisbert et al., 2005), red drum, (Buchet et al., 2000) and gilthead sea bream, (Coutteau et al., 1997; Fontagné et al., 1999; Izquierdo et al., 2001).

At the end of the experiment, the occurrence of scoliosis or jaw deformity was very low. Lordosis was the main skeletal deformity observed among pikeperch larvae and was generally related to the non inflation of swimbladder. This is in agreement with Chatain (1994) who demonstrated that the non inflation of swimbladder induced lordosis in sea bass larvae. In this study, inflation began on day 7 . On day 12 , at least $80 \%$ of larvae displayed a well inflated swimbladder. As the inflation began before the introduction of the microdiet, the non-inflation phenomenon should not be attributed to the diets.

Our study failed to evidence an effect of dietary PL level in preventing deformities, as it was observed by Cahu et al. (2003) in European sea bass larvae. These authors observed that for the highest dietary PL level $(12 \%)$ the sea bass larvae exhibited the lowest incidence (2\%) of skeletal deformities. The decrease of malformations with the increasing level of dietary PL has been reported by other authors (Kanazawa et al., 1981; Geurden et al., 1998). In our study, the intra treatment variability was high and may have masked the effect of the diet composition. Nevertheless, malformations were lower than in other studies, even when larvae were fed live preys (Hamza et al., 2007; Kestemont et al., 2007). Scoliosis is generally more related to a nutritional deficiency like dietary ascorbic acid level (Kestemont et al., 2007). There are few data on vitamin C requirements of first feeding larvae (Gouillou-Coustans et al., 1998) but it could be assumed that the ascorbic acid level in this diet was sufficient when compared with commercial diets (Kestemont et al., 2007). This assumption was supported by the almost total absence of scoliosis in these larvae.

The general pattern of digestive enzyme activities observed during pikeperch development in our experiment was similar to that described for other species like European sea bass (Cahu and Zambonino, 1994) and perch (Cuvier-Péres and Kestemont, 2002). The increase in brush border membrane enzymes, such as alkaline phosphatase and aminopeptidase $\mathrm{N}$, concurrently with the decrease of cytosolic enzyme, such as leu-ala peptidase reflected the normal maturation process of enterocytes (Cahu and Zambonino Infante, 1994). In this trial, leu-ala sharply decreased between days 16 and 22 when AP increased between day 10 and 16 . We can assume that AP activity reached its maximal value between day 16 and 22 and then decreased because of somatic growth.

AP is an esterase whose activity is induced by phosphorylated substrates such as phospholipids and phosphoproteins. Its specific activity was significantly higher in the PL9 and PL5 groups on day 22 while the larvae of the three treatments still had similar weights, and on day 28 . This higher AP activity 
suggests a better development and intestinal maturation process in PL9 and PL5 groups compared to the PL1 group, as was suggested in European sea bass larvae by Cahu and Zambonino (1994) and in senegalese sole by Ribeiro et al. (2002).

In this study, we observed that AP segmental activity was closely influenced by both age and treatment. AP segmental activity significantly increased with dietary PL level. On day 22, it was higher in PL5 and PL9 larvae while all the larvae had similar weights. AP has often been considered as a sensitive indicator of the nutritional status of larvae (Cahu and Zambonino, 1994; Ribeiro et al., 2002). The AN specific activity increased with the dietary PL level on day 22, even though PL is not a potential substrate for this enzyme. Again, this highlights the enhanced maturation of the intestine in larvae fed the high PL diet, as pointed out by Cahu et al. (2003) for European sea bass larvae. From day 28 onwards, no more differences were noticeable for AN specific activity. This can be explained by the fact that at that stage all larvae displayed a mature digestive tract. Indeed, Zambonino and Cahu (2001) associated an efficient brush border membrane digestion to the adult mode of digestion.

It seems that high dietary PL level improved gut maturation and larval development of pikeperch larvae as has been shown for red drum and European sea bass by Buchet et al. (2000) and Cahu et al. (2003), respectively.

Zambonino et al. (1997) considered AP/leu-ala and AN/leu-ala ratios as enterocyte maturation indices. In our work, the ratio of segmental activity of the brush border membrane enzyme AP related to the segmental activity of a cytosolic enzyme, leu-ala, which was significantly higher on day 28 in the PL5 and PL9 groups, compared to PL1, indicating that $1 \%$ PL incorporation in the diet was not sufficient to induce good enterocyte maturation. Earlier enterocyte maturation, leading to better nutrient absorption and incorporation, has been associated with the best growth obtained with diet PL9. The role of PL level in improving lipid absorption can be partly related with its effects on enzyme activity but more likely attributed to the enhancement of lipoprotein synthesis. Indeed, PL are known to be a structural component of lipoproteins, which play an essential role in the transport of NL (Coutteau et al., 1997; Fontagné et al., 1998).

The incorporation of a gradient level of PL from vegetable source (soybean lecithin), at the expense of marine NL (fish oil), increased the PL concentration of the diet and modified its fatty acid composition. Indeed, the fatty acid composition of the larvae was globally influenced by the fatty acid composition of the corresponding NL and PL fractions in the diet. The major effect of the dietary PL supplementation on larval fatty acid composition was an increase in the percentage of total $n-6$ (particularly 18:2n-6) in both NL and PL fractions. This increase was accompanied by a decrease in the percentage of $n-3$ fatty acids (especially 20:5n-3 and 22:6n-3). These changes in FA composition were similar to those observed in Atlantic salmon fed diets containing vegetable oils (Ruyter et al., 2006). A preferential deposition of certain fatty acids (18:2n-6) in the NL fraction was also observed in this study, as was shown by Rinchard et al. (2007) in rainbow trout juveniles fed different vegetable oils and lecithin. On the contrary, $n-6$ and n-3 HUFA seemed to be preferentially retained in the PL fraction of the larvae, as reported by Ruyter et al. (2006). These HUFA also seem to be conserved in larval tissues whatever their concentrations in the diet. Indeed, the magnitude of the differences in HUFA levels is attenuated in the fish compared to the diets. The relatively high levels of n-3 HUFA in PL9 larvae contrasting with their low level in PL9 diet could be attributed to an elongation and desaturation process of C18 fatty acids. Indeed, it has been shown that freshwater fishes like trout and salmon fed vegetable oils have the capacity to convert C18 to C20 and C22 by elongation and desaturation (Bell et al., 1993; Tocher et al., 1997; Buzzi et al., 1997). Schulz et al. (2005) demonstrated that juvenile pikeperch have the capacity for n-3 PUFA elongation and desaturation. This process could be more important when fish are fed low levels of n-3 HUFA (Buzzi et al., 1996; Caballero et al., 2002). Best results of growth in PL9 larvae could hence be due to higher levels of PUFA, particularly of 18:2n-6 and 18:3n-3, which are essential fatty acids for freshwater species. Moreover, a higher polyunsaturated/saturated fatty acid ratio was observed in the PL fraction of the PL9 diet, which resulted in the best growth and development in this group. This was also observed by Caballero et al (2002) who showed that an increase of this ratio in the diet improved apparent fatty acid digestibility.

In a review, Morais et al. (2007) reported several studies which attributed the growth depressing effect to a high dietary NL level which decreased the activity of digestive enzymes and the absorption efficiency. In this study, it may have been the case of the PL1 diet which contained the highest level of $\mathrm{NL}$. Indeed, on day 22 there was a correlation between PL level and brush border membrane enzyme activities. Furthermore, PL are known to play an essential role in lipid transport, particularly of triacylglycerol (Coutteau et al., 1997; Fontagné et al., 1998), thus affecting energy supply (Coutteau et al., 1997). In the same way, our results could indicate a better utilization of the available energy from dietary NL in larvae fed high dietary PL, as growth in the PL9 group was higher, even though larvae in the 3 groups were fed isoenergetic diets $\left(17.2\right.$ to $\left.18.0 \mathrm{~kJ} \mathrm{~kg}^{-1}\right)$. 
It is believed that fish larvae use more efficiently n-3 HUFA from the PL fraction than those from the NL fraction (Cahu et al., 2003; Gisbert et al., 2005; Villeneuve et al., 2005). The best growth and development (maturation of the digestive tract) were observed in PL9 larvae, although the levels of EPA+DHA in the PL fraction were similar (around $0.25 \%$ diet dry weight) in the different diets. Hence, the best growth observed in PL9 larvae was not due to a higher level of EPA+DHA in the dietary PL fraction. It is generally admitted that NL is not a very efficient way to supply EPA and DHA. Nevertheless, a negative effect of high EPA and DHA level in NL could be also suspected with our results, this level reaching $4 \%$ of dry matter in diet PL1.

\section{Conclusion}

The results of this study showed that pikeperch can be successfully weaned from day 10 with a compound diet, with satisfactory growth and survival. To our knowledge, this work is the first study that analysed a nutritional requirement of pikeperch at the larval stage. It appeared that a diet containing $9 \% \mathrm{PL}$ can support good growth and development in this species. The possibility of using a compound diet, with a formulation based on that of the PL9 diet, would allow conducting more detailed experiments to determine the specific nutritional requirements of pikeperch young developmental stages. In particular, HUFA dietary requirements, and their form of supply as NL or PL remains to be established.

\section{Acknowledgements}

This study was initiated by a cooperative project between INSTM (Tunisia) and FUNDP (Belgium) and supported by a CGRI-DRI grant, French speaking community of Belgium and Ministry of the Walloon Region. Authors wish to thank P. Quazuguel and H. le Delliou (IFREMER-INRA, France), M.C. Forget (FUNDP, Belgium), as well as W. Hammami, M. Arfi and S. Saïdi (INSTM, Tunisia) for their technical assistance. They also express their gratitude to Saloua Sadok (INSTM, Tunisia) for access to her laboratory.

\section{References}

Bell, M.V., Tocher, D.R., 1989. Molecular species composition of the major phospholipids in brain and retina from rainbow trout (Salmo gairdneri). J. Biochem. 264, 909-915.

Bell, J.G., Dick, J.R., Sargent, J.R., 1993. Effect of diets rich in linoleic or a-linolenic acid on phospholipid fatty acid composition and eicosanoid production in Atlantic salmon (Salmo salar). Lipids 28, 819-826.

Bessey, O.A., Lowry, O.H., Brock, M.J., 1946. Rapid coloric method for determination of alkaline phosphatase in five cubic millimetres of serum. J. Biol. Chem. 164, 321-329.

Bradford, M.M., 1976. A rapid sensitive method for the quantification of protein utilizing the principle of protein-dye binding. Anal. Biochem. 72, 248-254.

Brown, P.B., Dabrowski, K., Garling, D., 1996. Nutrition and feeding of yellow perch (Perca flavescens). J. Appl. Ichthyol. 12, 171-174.

Buchet, V., Zambonino Infante, J.L., Cahu, C.L., 2000. Effect of lipid level in a compound diet on the development of red drum (Sciaenops ocellatus) larvae. Aquaculture 184, 339-347.

Buzzi, M., Henderson, R.J., Sargent, J.R., 1996. The desaturation and elongation of linoleic acid and eicosapentaenoic acid by hepatocytes and liver microsomes from rainbow trout (Oncorhyncus mykiss) fed diets containing fish oil or olive oil. Bioch. Bioph. Acta 1299, 235-244.

Buzzi, M., Henderson, R.J., Sargent, J.R., 1997. The biosynthesis of docosahexaenoic acid (22:6n-3) from linolenic acid in primary hepatocytes isolated from wild northern pike. J. Fish. Biol. 51, 11971208.

Caballero, M.J., Obach, A., Rosenlund, G., Montero, D., Gisvold, M., Izquierdo, M.S., 2002. Impact of different lipid sources on growth, lipid digestibility, tissue fatty acid composition and histology of rainbow trout, Oncorhyncus mykiss. Aquaculture 214, 253-271.

Cahu, C.L., Zambonino, J.L., 1994. Early weaning of sea bass (Dicentrarchus labrax) larvae with a compound diet: effect on digestive enzymes. Comp. Biochem. Physiol. 109A, 213-222. 
Cahu, C.L.., Zambonino Infante, J.L., Barbosa, V. 2003. Effect of dietary phospholipid level and phospholipid:neutral lipid value on the development of sea bass (Dicentrarchus labrax) larvae fed a compound diet. Br. J. Nutr. 90, 21-28.

Chatain, B., 1994. Abnormal swimbladder development and lordosis in sea bass (Dicentrarchus labrax) and sea bream (Sparus auratus) larvae. Aquaculture 119, 371-379.

Coutteau, P., Geurden, I., Camara, M.R., Bergot, P., Sorgeloos, P., 1997. Review on the dietary effects of phospholipids in fish and crustacean larviculture. Aquaculture 155, 149-164.

Cuvier-Péres, A., Kestemont, P., 2002. Development of some digestive enzymes in Eurasian perch larvae Perca fluviatilis. Fish Physiol. Bichem. 24, 279-285.

Diaz, J.P., Mani-Ponset, L., Guyot, E., Connes, R., 1997. Biliary lipid secretion during early post embryonic development in three fishes of aquacultural interest: Sea bass (Dicentrarchus labrax L., sea bream Sparus aurata and pike perch Stizostedion lucioperca (L.) J. Exp. Zool. 277, 365-370.

Fiogbé, E.D., Kestemont, P., Mélard, C., Micha, J.C., 1996. The effects of dietary crude protein on growth of the Eurasian perch Perca fluviatilis. Aquaculture 144, 239-249. Folch, J., Lees, M., Stanley, G.H.S., 1957. A simple method for the isolation and purification of total lipids from animal tissues. J. Biol. Chem. 226, 497-509.

Fontagné, S., Geurden, I., Escaffre, A.M., Bergot, P., 1998. Histological changes induced by dietary phospholipids in intestine and liver of common carp (Cyprinus carpio L.) larvae. Aquaculture 161, 213223.

Fontagné, S., Pruszynski, T., Corraze, A.-M., Bergot, P., 1999. Effect of coconut oil and tricaprylin vs triolein on survival, growth and fatty acid composition of common carp (Cyprinus carpio L.) larvae. Aquaculture 161, 213-223.

Fontagné, S., Burtaire, L., Corraze, G., Bergot, P., 2000. Effects of medium-chain triacylglycérols (tricaprylin and tricaproin) and phospholipid supply on survival, growth and lipid metabolism in common carp (Cyprinus carpio) larvae. Aquaculture 190, 289-303.

Geurden, I., Radünz-Neto, J., Bergot, P., 1995. Essentiality of dietary phospholipids for carp (Cyprinus carpio L.) larvae. Aquaculture 131, 303-314.

Geurden, I., Marion, D., Charlon, N., Coutteau, P., Bergot, P., 1998. Comparison of different soybean phospholipidic fractions as dietary supplements for common carp, Cyprinus carpio, larvae. Aquaculture 161, 225-235.

Gisbert, E., Villeneuve, L., Zambonino Infante, J.L., Quazuguel, P., Cahu, C.L., 2005. Dietary phospholipids are more efficient than neutral lipids for long chain polyunsaturated fatty acid supply in European sea bass Dicentrarchus labrax development. Lipids 40, 1-10.

Gouillou-Coustans, M.F., Bergot, P., Kaushik, S.J., 1998. Dietary ascorbic acid needs of common carp (Cyprinus carpio) larvae. Aquaculture 161, 453-461.

Hamza, N., Mhetli, M., Kestemont, P., 2007. Effects of weaning age and diets on ontogeny of digestive activities and structures of pikeperch (Sander lucioperca) larvae. Fish Physiol. Biochem. 33, 121-133.

Hilge, V., Steffens, W., 1996. Aquaculture of fry and fingerling of pikeperch (Stizostedion lucioperca L.) A short review. J. Appl. Ichthyol. 12, 167-170.

Izquierdo, M.S., Tandler, A., Salhi, M., Kolkovski, S., 2001. Influence of dietary polar lipids quantity and quality on ingestion and assimilation of labelled fatty acids by larval gilthead sea bream. Aquac. Nutr. 7, 153-160.

Juaneda, P., Rocquelin, G., 1985. Rapid and convenient separation of phospholipids and non phosphorus lipids from rat heart using silica cartridges. Lipids 30, 40-41.

Kanazawa, A., Teshima, S.I., Ono, K., 1979. Relationship between essential fatty acid requirements of aquatic animals and the capacity for bioconversion of linolenic acid to highly unsaturated fatty acids. Comp. Biochem. Physiol. 63B, 295-298.

Kanazawa, A., 1985. Essential fatty acid and lipid requirement of fish. In: C.B. Cowey, A.M. Mackie, J.G. Bell (Eds). Nutrition and feeding in fish. Academic Press, London.

Kanazawa, A.,1991. Essential phospholipids of fish and crustaceans. In: INRA (Eds.), Fish nutrition in Practice, Biarritz (France) June 24-27, 1999. Paris 1993 (Les colloques Nº1).

Kanazawa, A., Teshima, S.I., Sakamoto, M., 1985. Effects of dietary lipids, fatty acids, and phospholipids on growth and survival of prawn (Penaeus japonicus) larvae. Aquaculture 50, 39-49.

Kestemont, P., Mélard, C., Fiogbé, E., Vlavonou, R., Masson, G., 1996. Nutritional and animal husbandry aspects of rearing early life stages of Eurasian perch Perca fluviatilis. J. Appl. Ichthyol. 12, 157-165.

Kestemont, P., Mélard, C., 2000. Aquaculture Chap. 11 In: Craig, J.F.(Ed.) Percid Fishes Systematics, Ecology and Exploitation. Blackwell Science, Oxford, UK. 
Kestemont, P., Vandeloise, E., Mélard, C., Fontaine, P., Brown, P.B., 2001. Growth and nutritional status of Eurasian perch Perca fluviatilis fed graded levels of dietary lipids with or without ethoxyquin. Aquaculture 203, 85-99.

Kestemont, P., Xueliang, X., Hamza, N., Maboudou, J., Imorou Toko, I., 2007. Effect of weaning age and diet on pikeperch larviculture. Aquaculture 264, 194-204.

Klein Breteler, J.G.P., 1989. Intensive culture of pike-perch fry with live food. In: N. De Pauw, E. Jaspers, H. Ackefors, N. Wilkins (Eds). Aquaculture- A biotechnology in Progress. E.A.S., Bredene Belgium.

Koven W.M., Kolkovski, S., Tandler, A., Kissil, G.Wm. Sklan, D., 1993. The effect of dietary lecithin and lipase, as function of age, on n-9 fatty acid incorporation in the tissue lipids of Sparus aurata larvae. Fish Physiol. Biochem. 10, 357-364.

Koven, W.M., Parra, G., Kolkovski, S., Tandler, A., 1998. The effect of dietary phosphatidylcholine and its constituent fatty acids on microdiet ingestion and fatty acid absorption rate in gilthead sea bream, Sparus auratus, larvae. Aquacult. Nutr. 4, 39-45.

Mani-Ponset, L., Diaz, J.P., Schlumberger, O., Connes, R., 1994. Development of yolk complex, live rand anterior intestine in pike-perch larvae, Stizostedion lucioperca (Percidae), according to the first diet during rearing. Aquat. Living Resour. 7, 191-202

Maroux, S., Louvard, D., Baratti, J., 1973. The aminopeptidase from hog-intestinal brush border. Biochim. Biophys. Acta 321, 282-295.

Metcalfe, L.D., Schmitz, A.A., Pelka, J.R., 1966. Rapid preparation of fatty acid esters from lipids for gas chromatographic analysis. Ann. Chem. 38, 524-535.

Molnar, T., Hancz, Cs., Molnar, M., Horn, P., 2004. The effects of diet and stocking density on the growth and behaviour of pond pre-reared pikeperch under intensive conditions. J. Appl. Ichthyol. 20, 105-109.

Molnar, T., Szabo, A., Szabo, G., Szabo, C., Hancz, C., 2006. Effect of dietary fat content and fat type on the growth and body composition of intensively reared pikeperch Sander lucioperca (L.). Aquacult. Nutr. 12, 173-182.

Morais, S., Cahu, C., Zambonino-Infante, J.L., Robin, J., Ronnestad, I., Dinis, M.T., Conceição, L.E.C., 2004. Dietary source and level affect performance and lipase expression in larval sea bass (Dicentrarchus labrax). Lipids, 39, 1-10.

Morais, S., Conceição, L.E.C., Ronnestad, I., Koven, W., Cahu, C., Zambonino Infante, J.L., Dinis, M.T., 2007. Dietary neutral lipid level and source in marine fish larvae: Effects on digestive physiology and food intake. Aquaculture 268, 106-122.

Nicholson, J.A., Kim, Y.S., 1975. A one-step L-amino acid oxidase assay for intestinal peptide hydrolase activity. Anal. Biochem. 63, 110-117.

Nyina-Wamwiza L., Xu X.L., Blanchard G., Kestemont, P., 2005. Effect of dietary protein, lipid and carbohydrate ratio on growth, feed efficiency and body composition of pikeperch Sander lucioperca fingerlings. Aquacult. Res. 36, 486-492.

Ostaszewska, T., Dabrowski, K., Czuminska, K., Olech, W., Olejniczak, M., 2005. Rearing of pikeperch larvae using formulated diets-first success with starter feeds. Aquacult. Res. 36, 1167-1176.

Proteau, J.P., Schlumberger, O., Albiges, C., 1993. Sandre: des efforts encore sur la reproduction et élevage larvaire. Aquacult. Revue 47, 23-26.

Rainuzzo, J.R., Reitan, K.I., Olsen, Y., 1997. The significance of lipids at early stages of marine fish: a review. Aquaculture 155, 103-115.

Ribeiro, L., Zambonino Infante, J.L., Cahu, C., Dinis, M.T., 2002. Digestive enzymes profile of Solea senegalensis post larvae fed Artemia and a compound diet. Fish Physiol. Biochem. 27, 61-69.

Rinchard, J., Czesny, S., Dabrowski, K., 2007. Influence of lipid class and fatty acid deficiency on survival, growth, and fatty acid composition in rainbow trout juveniles. Aquaculture 264, 363-371.

Ruuhijärvi, J., Virtanen, E., Salminen, M., Muyunda, M., 1991. The growth and survival of pike-perch, Stizostedion lucioperca L., larvae fed on formulated feeds. In: Larvi'91. Fish and Crustacean Larviculture Symposium. E.A.S. Spec. Publ. N¹5, Gent Belgium.

Ruyter, B., Moya-Falcon, C., Rosenlund, G., Vegusdal, A., 2006. Fat content and morphology of liver and intestine of Atlantic salmon (Salmo salar): Effects of temperature and dietary soybean oil. Aquaculture 252, 441-452.

Sargent, J., Bell, G., Mc Evoy, L., Tocher, D., Estevez, A., 1999. Recent developments in the essential fatty acid nutrition in fish. Aquaculture 177, 191-199.

Schlumberger, O., Proteau, J.P., 1991. Production de juvéniles de sandre (Stizostedion lucioperca). Aqua Revue 36, 25-28. 
Schulz, C., Knaus, U., Wirth, M., Rennert, B., 2005. Effects of varying dietary fatty acid profile on growth performance, fatty acid, body and tissue composition of juvenile pikeperch (Sander lucioperca). Aquacult. Nutr. 11, 403-413.

Schulz, C., Günther, S., Wirth, M., Rennert, B., 2006. Growth performance and body composition of pike perch (Sander lucioperca) fed varying formulated and natural diets. Aquacult. Int. 14, 577-586.

Teshima, S.I., Kanazawa, A., Kakuta, Y., 1986. Effects of dietary phospholipids on growth and body composition of the juvenile prawn. Bull. Jpn. Soc. Sci. Fish. 52, 155-158.

Tocher, D.R., 2003. Metabolism and functions of lipids and fatty acids in teleost fish. Reviews Fish. Sc. 11, 1-78.

Villeneuve, L., Gisbert, E., Zambonino Infante, J.L., Quazuguel, P., Cahu, C.L, 2005. Effect of nature of dietary lipids on European sea bass morphogenesis: implication of retinoid receptors. Br. J. Nutr. 94, 877-884.

Zakes, Z., 1997. Converting pond-reared pikeperch fingerlings, Stizostedion lucioperca (L.) to artificial food- effect of temperature. Arch. Pol. Fish. 5, 313-324.

Zakes, Z., 1999. The effect of body size and water temperature on the results of intensive rearing of pike-perch Stizostedion lucioperca (L.) fry under controlled conditions. Arch. Pol. Fish. 7, 187-199.

Zambonino Infante, J.L., Cahu, C.L., 1999. High dietary lipid levels enhance digestive tract maturation and improve Dicentrarchus labrax larval development. J. Nutr. 129, 1195-1200.

Zambonino Infante, J.L., Cahu, C.L., 2001. Ontogeny of the gastrointestinal tract of marine fish larvae. Comp. Biochem. Physiol. 130C, 477-487.

Zambonino Infante, J.L., Cahu, C.L., Péres, A., 1997. Partial substitution of di-and tripeptides for native proteins in sea bass diet improves Dicentrarchus labrax larval development. J. Nutr. 127, 608614.

Zar, J.H., 1999. Biostatistical Analysis, $4^{\text {th }}$ edition. Prentice Hall, Englewood Cliffs. 663 pp. 